\title{
Biblioteca Moderna e a Documentação
}

MARIA Vido

A

tendência da Biblioteca Moderna é tornar-se um Centro de Documeñtação. Enfrentaremos por isso, o estudo do documento, tendo em vista a resolução de seus problemas capitais.

A nosso ver, a maior falha dos programas, até então traçados para as nossas bibliotecas, tem sido a inabilidade em acompanhar os adiantamentos das técnicas modernas, relacionados com a crescente expansão das atividacies que dão lugar ao aparecimento de papéis, livros, panfletos, documentos em geral etc... Para corrigir tal situação, deverá ser dada nova orientação aos programas, a fim de que, futuramente, a Biblioteca Moderna, agindo como um Centro de Documentação, possa dar maior assistência à solução dos problemas criados pelos documentos - o que proporcionará ao pesquisador, todos os recursos das técnicas modernas da documentação, facilitando-lhe o trabalho de suas pesquisas e permitindo-lhe a reaiização de novas descobertas no campo da ciência. guintes:

tintre os problemas criados pela documentação, assinalaremos os se-

a) Projetos dos Edifíicios Públidos: Mais atenção deve ser dada, nos projetos dos edifícios públicos às medidas que visem melhorar as condições de guarda dos documentos. A atenção deve ser dirigida, geralmente, para a coleta de dados sôbre as exigências de espaço, proteção, acessibilidade e sôbre os detalhes de construção das áreas para guarda dos docamentos.

b! Futncionários Especializados: São poucos os funcionários especializados em material de arquivo, tendo assim de ficar na dependência dos vendedores dêsse equipamento para obterem as mais recentes informações sôbre os diversos sistemas de arquivamento. O resultado nem sempre é satisfatorio. Seria acciselhável que, de preferência, sejam selecionados funcionários que tenham um curso especializado sôbre os diversos sistemas de arquivamento, assim como, prática suficiente para trabalhar com material fotostátrco, microfilmagem, formulários etc... - o que concorrerá para o pleno êxito dêste importalnte trabalho.

c) Eliminação ou doação de documentos: Possivelmente, uma das mais importantes considerações, no avaliar os documentos para a eliminação 
ou doação, é a da possibilidade de terem os mesmos valor contínuo tanto para a repartição ou órgão que lhes deu origem, como para a que os vai conservar. A pesquisa poderia revelar, tão acuradamente quanto possivel, a trequêericia de seu uso e se os documentos são originais ou duplicatas, para isso, uma informação mais específica torna-se necessária. Esta informação é melhor obtida através do funcionário que mantém o documento. Sua opinião não deveria, contudo, ser a última palavra sôbre o assunto; ela deveria ser comparada com opinióes de outras fontes, particularmente com aquelas, que deram origem ao documento, por indicação de outro órgão. $\mathrm{Em}$ tal caso, o órgão que requer a criação do documento também deveria ser consultado.

d) Documentos de valor administrativo: Evidentemente, os documentos que possuem valor administrativo contínuo não devem receber aprovação para destruição. Quanto às cópias, podem, muitas vêzes, ser destruídas, se os originais forem retidos, mas um estuda prévio deveria ser feito para aprovação de tais destruições, especiálmente quando os originais não estão arquivados na mesma repartição. Vários documentos vão perdendo a utilidade com o correr dos anos. Assim, muitas vêzes, podem se: destruidos após a expiração de um periodo de retenção. Ocasionalmente, os documeintos, em particular os subsidiários que seguem para constituir um documento permanente, podem ser destruidos, porque a informação que rontêm está preservada em algum lugar.

e) Valor da pesquisa do documento: É, sob alguns aspectos, o de mais dificil determinação, uma vez que é impossivel delimitar-se, com segurança, para onde se dirigirá, exatamente, a pesquisa futura e quais os tipos de documentos que a ela serão necessários. Tem sido observado que os documentos que mais se acumulam nas repartições, raramente têm um alto valor de pesquisa. $\mathrm{Na}$ maior parte, êles são, ou duplicata de documentos que estão guardados em qualquer parte, ou documentos subsidiários que loram usados na preparação de alguns documentos permanentes. Nios casos em que tivessem, em parte, valor para fins de pesquisa ou êsse valor fôsse temporário, os documentos seriam guardados, podendo ser sempre, mais farde, reaparecidos.

i) Conservação dos documentos: Os elementos que integram o material da escrita são de natureza orgânica, sujeitos portanto, a riscos e alterações da matéria viva. A umidade excessiva, a temperatura exagerada, a talta de arejamento num depósito de livros ou documentos; o armazenamento prolongado do pó, a existência de bactérias, insetos, e ainda, os estragos que poderão ser produzidos pela guerra moderna, são causas cujos efeitos mais ou menos rápidos e devastadores só poderão ser combatidos com os métodos e técnicas recentes da nova patologia e terapêutica aplicada aos documentos em geral. Tendo em vista a conservação dos documentos, recorremos a conclusóes práticas e simples que possam ser imediatamente aplicadas tais como:

1 - Restauração dos documentos: Como a restauração de documentos gravemente danificados é uma operação delicada e 
custosa, que pede material adequado e técnicas de rara competência profissional, aconselhariamos a criação de um Laboratório Central (único), para onde convergiriam todos os livros e documentos em geral que merecessem restauração radical.

II - Limpeza dos documentos: Todo depósito de documentos e livros deverá ser periòdicamente submetido a uma limpeza rigorosa (aspiração do pó, arejamento e desinfecção). Quando fôr necessária uma desinfecção radical à base de ácido cianidrico ou outro tóxico altamente perigoso, a execução deverá ser feita por pessoas especializadas nesta técnica.

III - Prática dos Serviços de Restauração e Desinfecção dos documentos: Há conveniência de que o pessoal de um Centro de Documentação ou Biblioteca tenha alguma prática dos serviços de restauração e desinfecção dos documentos em geral, o que auxiliará a conservação dos mesmos. Só deverão ser enviados ao Laboratório Central (único) os documentos que estejam completamente danificados.

IV - Microfilme: Nenhum outro meio técnico da documentação tem tido o êxito da microfotografia, principalmente, com relação à conservação de documentos. Nos paises estrangeiros tem resolvido problemas de organização, classificação, espaço e economia que afetam arquivos particulares e aquêles outros relativos à moderna e desmesurada burocracia estatal; tem facilitado uma conservação mais eficiente dos documentos importantes custodiados nos arquivos históricos, evitando seu emprêgo e desgaste continuo, mediante a utilização da microfotografia; pelo procedimento de arquivar as cópias microfotografadas em lugares distintos daqueles em que se encontram os originais tem contribuido para a seguridade desta mesma documentação, evitando o risco de acidentes; e tem procurado, por último, uma maior liberdade de consulta e intercâmbio da documentação, que tem facilitado ao pesquisador o livre acesso aos arquivos, bibliotecas etc.

Aconselhariamos, dado ao volume ingente do material para microfilmar e o elevado custo de sua implantação, a centralização dêste importantissimo serviço, tendo por principal objetivo a microtilmagem dos fundos documentais básicos do país. O Serviço Cientral de «Microfilme» permitirá lograr a proteção dos fundos documentais mediante a custódia dos correspondentes negativos em condições adequadas à máxima seguridade, permitindo, ainda, a remessa a cada Centro de Documentação de duplicatas microfotográficas.

Por sua vez, todo Arquivo importante, contaria com uma equipe particular que lhe permitisse atender aos pesquisadores e, ainda, constituir seu próprio arquivo microfotográfico, ficando assim obrigado a remeter ao Serviço Central de «Microfilme» uma duplicata de todos os seus documentos microfotografados. 


\section{CONCLUSÃO}

A solução dos problemas ora apresentados dependerá em grande parte da iniciativa daqueles que dirigem os principais Centros de Documentação de nosso país. A iniciativa seria coroada de êxito se tivesse como ponto de partida a criação de um CURSO INTENSIVO DE DOCUMENTAÇÃO, asSim como, a realização de uma SÉRIE DE CONFERÊNCIAS, tendo como principal objetivo a atualização das técnicas modernas da documentação. Conseguiríamos, assim, o máximo de progresso para as nossas Bibliotecas e Centros de Documentação.

Esperamos, finalmente, que com a divulgação de um assunto de capital importância como o é - a Biblioteca Moderna, agindo como um Centro de Documentação - seja dada, futuramente, maior atenção aos problemas criados pelos documentos no Brasil. 